\title{
EXPERIMENTAL RESEARCH OF ENERGY-POWER PARAMETERS OF VANE CLEANER OF BEET ROOT HEADS WITH HORIZONTAL DRIVE SHAFTS
}

\author{
Volodymyr Bulgakov ${ }^{1}$, Semjons Ivanovs ${ }^{2}$, Francesco Santoro ${ }^{3}$, Alexandros Sotirios Anifantis ${ }^{3}$ \\ ${ }^{1}$ National University of Life and Environmental Sciences of Ukraine, Ukraine; ${ }^{2}$ Latvia University of \\ Life Sciences and Technologies, Latvia; ${ }^{3}$ University of Bari Aldo Moro, Italy \\ semjons@apollo.lv, francesco.santoro@uniba.it, alexandrossotirios.anifantis@uniba.it
}

\begin{abstract}
Removing the root crop tops is a highly time-consuming process and it affects the quality and safety of the resulting product. In order to study the technological and energy parameters of the sugar beet heads, i.e. to remove the top residues after the main, complete separation of the haulm, we have developed a new experimental setup that allows simulation of the operation of individual samples of various types of cleaners and conduct experimental research under the field conditions. The structural diagram of this setup is universal, and it consists of the main frame, which is hung on the rear side of the wheeled aggregating tractor by means of a suspension linkage. Inside the main frame there is a rotary frame mounted, operated by means of a rotary beam that is necessary for hanging horizontal cleaning working tools on it, and they can be installed due to the rotary beam at various angles to the field surface and to the direction of the forward movement. The installation height of the cleaning working tools is regulated with the help of the feeler wheels, and the position of the wheels relative to the frame can be changed due to the design of their attachment to the frame. As a result of statistical processing of the results of strain gauging on the $\mathrm{PC}$, it was found that the maximum value of the required power on the drive of the working bodies of the cleaner can reach $2.5 \mathrm{~kW}$, and a similar value of traction power does not exceed $0.24 \mathrm{~kW}$. On the whole, the total maximum power of this sugar beet cleaner from the tops (remaining leaves) without extracting the sugar beet heads from the ground with horizontal drive shafts is $2.74 \mathrm{~kW}$, which is 1.3 times less than commercially available cleaners spend on it.
\end{abstract}

Keywords: sugar beet, cleaner, soil, power.

\section{Introduction}

Sugar beet is one of the important agricultural crops in many European countries [1-2]. In the sugar beet harvesting process the most significant technological operations are digging the root crops out of the soil and removing the uncut leaves [3-4]. Sugar beet tops have good nutritional properties and can be used as feed in animal husbandry both in green form and as silage [5-6].

Modern technologies of harvesting sugar beets assume separate harvesting of the tops and the root crops, namely, cutting the tops without extracting the beets from the soil and subsequent extraction from the soil of the root crops. Besides, the removal of the tops is carried out in two stages: continuous basic cutting of the green mass of the tops and subsequent trimming of the heads, or cleaning the heads from the remains of the tops. All of the above operations of harvesting the tops are carried out without extraction the root crops from the soil, i.e. when the bodies of the sugar beet roots are in the soil.

Trimming the heads of the root crops after a continuous main cut of the tops takes place by additional cutters of a simple design, but it has a significant shortcoming - significant weight loss of the root crops (the trimmed heads remain on the field), and, consequently, the sugar-bearing mass. It has been established that, together with the irretrievable losses of the trimmed heads of the root crops, the potential yield of sugar from each hectare of the sugar beet crops is lost, sometimes reaching 8$10 \%$ [7]. In this regard, the exclusion from the technology of harvesting the sugar beet tops of the operation of trimming the upper heads of root crops is more promising. Therefore, the post-treatment of the root heads from the remains of tops without extracting the root crops from the ground is an urgent, economically justified operation, which, with high-quality raw materials, can significantly save the yield of the final product from a unit of the harvested area [7].

There are large numbers of designs of the after-cleaners for the sugar beet heads without their extraction from the soil. In addition, a large class of designs is made up of after-cleaners, which remove the remains of the tops by a single working tool (most often it is the horizontal drive shaft with elastic blades, mounted on it) that performs simultaneously cleaning using the entire working width of the top removing machine. The second class of the root crop head cleaners is when each row is cleaned by a separate working tool (most often it is a vertical drive shaft with cleaning blades, fixed at the end). The advantage of the first class cleaners of the root crop heads from the remains is a simple design and less metal consumption, but the disadvantages are the poor quality of cleaning of the side 
surfaces of the root crop heads from the remnants of the leaves, as well as their front parts. The advantages of the second class after-cleaners are the higher quality of cleaning of all spherical surfaces of the root heads in a row, but the disadvantages are the design complexity (especially in the multi-row version) and increased material consumption. It should be noted that high quality indicators of the second-class after-cleaners can be achieved only with a relatively low forward speed. As a rule, to completely remove the tops, each cleaning working tool should spend more time for processing each head. We have made an attempt to combine the basic design features of both after-cleaner classes of cleaning the root crop heads from the remains of the tops. The after-cleaner of the root heads from the remains of tops without extraction of the heads from the soil, built according to this principle, was first investigated by us during experimental field studies.

We have developed a new design for a cleaner of the heads of sugar beet roots from the remains of the tops without extracting the root crops from the soil after an increased continuous cut of the massif of the tops with a rotary top-cutting apparatus. The design feature of this subsequent cleaner is the presence of two drive cleaning shafts with horizontal rotation axes, which cover a row of the sugar beet root from two sides. These shafts of a certain length can be located in parallel, and can be installed at an angle to each other, creating a so-called treatment channel, which is larger in the front and, on the contrary, smaller in the rear. On the shafts, in radial directions, elastic cleaning blades are pivotally fixed with the help of special clips in such a way that on each shaft, along its length, the blades are fixed with a certain step. In addition, the shafts with the indicated clips (the cleaning blades) are mounted on a frame so that the ends of the radially fixed blades of one shaft are located opposite the gaps between the blades of the second shaft. The shafts have an ability to rotate in one direction, or in opposite directions of rotation.

The aim of the investigation is to experimentally determine under real field conditions the energy indicators of the new cleaner of the sugar beet heads from the remnants of the tops without extracting the heads from the ground depending on the speed of movement.

\section{Materials and methods}

To study the energy parameters of this cleaner of the root heads from the remains of tops without extraction of the heads from the ground, we have developed an experimental field installation that allows under real conditions of the beet field to simulate the operation of the single specimen of a cleaner of the root crop heads of this type. Figure 1 shows a general view of the field installation for conducting experimental studies of the root crop cleaner from the remains of the tops without extracting the root from the ground. The experimental field installation is aggregated with a class 1.4 wheeled tractor.

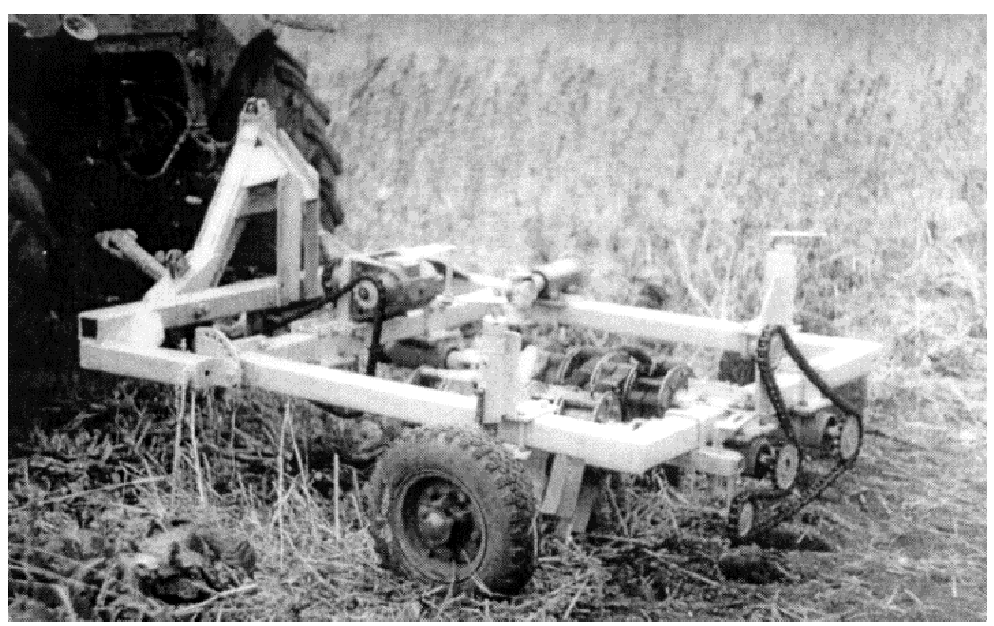

Fig. 1. General view of the experimental installation for studying cleaning of the root crop heads from the remnants of tops, attached to a wheeled aggregating tractor, class 1.4

The design of this blade cleaner of the root crop heads from the remains of tops is protected by the patent of Ukraine [9].

Fig. 2 shows a structural and technological scheme of the experimental installation with a new beet root head cleaner from the remains of tops without extracting the beet root heads from the ground. 
The experimental field installation consists of the main frame 1, which is mounted on the aggregating tractor, using ahitch attachment 4 . A rotary frame 2 is mounted on the main frame 1 by help of a rotary beam 3 . The rotary frame 2 is necessary for hanging on it the cleaning working bodies of the root heads with horizontal drive shafts, and it can be installed, thanks to the rotary beam 3 , at various angles to the surface of the beet field.

The work of the experimental field installation is performed in a floating position, but the installation height of the cleaning working bodies relative to the level of the soil surface is regulated using the copy wheels 5 . The position of the copy wheels relative to the frame 1 may vary due to the design of the screw mechanisms for their attachment to the frame 1.

During the operation the rotary frame 2 with the cleaning working bodies 11 with the horizontal drive shafts, which embrace the row of sugar beet roots from two sides, is oriented along the row from which the main mass of tops has been previously cut, but its remains are still left. The cleaning working bodies 11 are rotationally driven by a cardan gear 8 from the power take-off shaft of the aggregating tractor through a bevel gear 6 . Then from it, by help of a chain transmission, reducer 7 is activated, which is mounted on a rotary beam 3, due to which the cleaning working bodies 11 are driven by transmission through the chain 9 and cardan 10 gears. Due to the presence of a removable mount and a cardan drive 10, the cleaning working bodies 11 can be installed not only strictly along or across the row of sugar beet crops, but also at an angle of attack in both cases, which provides more opportunities for research.

a)

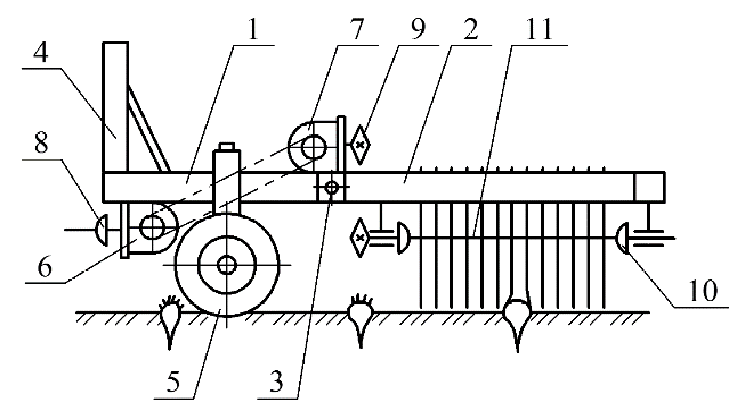

b)

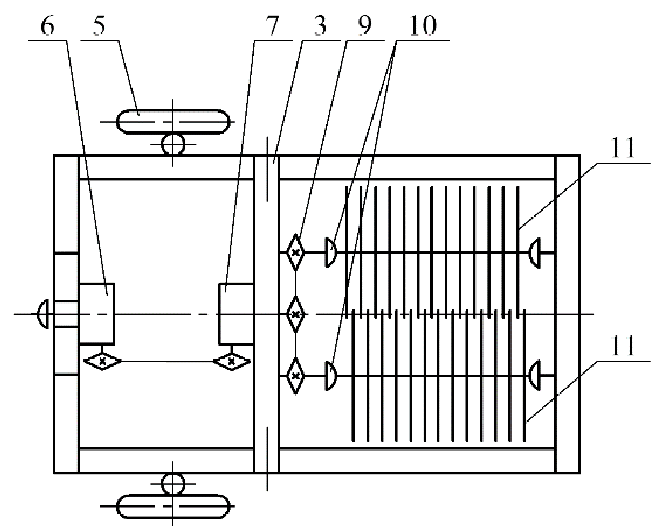

Fig. 2. Structural and technological scheme of the experimental field installation for research of the root head cleaner with horizontal drive shafts: $a$ - side view; $b$ - top view

When conducting the experimental field studies, instruments and tensometric equipment were used, which sent signals directly to the PC that performed statistical calculations of the fixed parameters. For the experimental field studies of the energy characteristics of the developed root head cleaner from the tops, the installation was equipped with strain gauge sensors that make it possible to measure the values of the resistance moments on the drive of the working bodies, to record the forward speed; as well as strain gauge sensors mounted on the drive axles of the aggregating tractor, which also take readings of the resistance moment and the number of revolutions that occur on the tractor semi-axles. This made it possible to measure and fix the traction resistance of the improved cleaning working body. In Figures 3 and 4 there are shown sensors used in the experimental studies: a strain gauge for the drive of the cleaning working bodies of the new root head cleaner and a measuring wheel, attached to the main frame of the experimental setup, to record the speed of the forward movement.The strain gauge sensor (Fig. 3) makes it possible to measure the moment of resistance on the tractor power take-off shaft and the angular rotation speed of the cleaning working body. Using a track measuring wheel (Fig. 4), the forward speed of the experimental installation along the axis of a row of the sugar beet crops was measured. The field experiments were carried out at three speeds of the experimental installation $(1,3,5$ - lowered speeds of the tractor $70 \mathrm{~kW})$. The experimental field studies of the sugar beet head cleaner from the remains of tops without extraction the head from the ground with horizontal drive shafts were carried out with such general characteristics of the field conditions and indicators of the beet plantation during the experimental studies [8], which are presented in Table 1. 
Characteristics of the field conditions, in which the experimental investigations of the root head cleaner with horizontal drive shafts have been conducted

\begin{tabular}{|c|c|}
\hline Fixed indicator & Value \\
\hline $\begin{array}{l}\text { Characteristics of sugar beet plantation: } \\
\text { Deviation of root crops from the axis of the row, \% } \\
0 \mathrm{~mm} \\
\pm 10 \mathrm{~mm} \\
\pm 20 \mathrm{~mm} \\
\pm 30 \mathrm{~mm} \\
\pm 40 \mathrm{~mm}\end{array}$ & $\begin{array}{c}7.2 \\
15.8 \\
20.9 \\
30.9 \\
25.2\end{array}$ \\
\hline $\begin{array}{l}\text { Placement of the sugar beet heads relative to the level of the soil } \\
\text { surface, } \% \\
\text { more than } 30 \mathrm{~mm} \\
\text { from } 20 \text { to } 30 \mathrm{~mm} \\
\text { from } 0 \text { to } 20 \mathrm{~mm} \\
\text { from } 0 \text { to }+20 \mathrm{~mm} \\
\text { more than }+20 \text { to }+40 \mathrm{~mm} \\
\text { more than }+40 \text { to }+60 \mathrm{~mm} \\
\text { more than }+60 \text { to }+80 \mathrm{~mm} \\
\qquad+80 \mathrm{~mm}\end{array}$ & $\begin{array}{c}0.0 \\
0.0 \\
0.0 \\
36.4 \\
22.7 \\
19.3 \\
11.4 \\
10.2\end{array}$ \\
\hline $\begin{array}{l}\text { Width of the main row spacing: medium, } \mathrm{cm} \\
\text { standard deviation, } \pm \mathrm{cm}\end{array}$ & $\begin{array}{c}44.5 \\
1.0\end{array}$ \\
\hline $\begin{array}{l}\text { Placement of root crops in a row of plantations: average distance } \\
\text { between the beet roots, } \mathrm{cm}\end{array}$ & $26.8 \pm 1.5$ \\
\hline Density of the root crop plantation, thousand units $\cdot(\text { ha })^{-1}$ & $82.9 \pm 1.1$ \\
\hline Root crop yield, $\mathrm{t} \cdot \mathrm{ha}^{-1}$ & $53.3 \pm 0.7$ \\
\hline Top foliage yield, $\mathrm{t} \cdot \mathrm{ha}^{-1}$ & $13.3 \pm 0.4$ \\
\hline $\begin{array}{ll}\text { Shape of the tops on the root crop heads by the nature of the } \\
\text { placement of leaves, } \%: & \begin{array}{l}\text { rosette } \\
\text { semi-rosette } \\
\text { cone }\end{array}\end{array}$ & $\begin{array}{l}21.1 \\
50.8 \\
28.1\end{array}$ \\
\hline Type of soil by mechanical composition & Black earth of low humus \\
\hline Field relief & Smooth \\
\hline 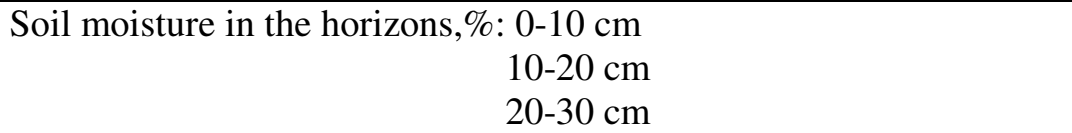 & $\begin{array}{l}22.5 \\
22.1 \\
22.6\end{array}$ \\
\hline $\begin{array}{lr}\text { Soil hardness in the horizons, MPa: } \begin{array}{r}0-10 \mathrm{~cm} \\
10-20 \mathrm{~cm}\end{array} \\
\end{array}$ & $\begin{array}{l}1.1 \\
2.0\end{array}$ \\
\hline Weediness of the beet field: weed plants, $\mathrm{pcs} \cdot \mathrm{m}^{-2}$ up to $100 \mathrm{~cm}$ high & 4.0 \\
\hline Crop preceding the cultivation of sugar beets, the la & $\begin{array}{l}\text { Winter wheat, loosening } \\
\text { of the interrow-spacings }\end{array}$ \\
\hline
\end{tabular}

The exact value of the forward speed $V$ of the experimental field installation, fixed by the track measuring wheel (Fig. 4), corresponds to the values of the following real speeds: $0.75 ; 1.5$ and $2.1 \mathrm{~m} \cdot \mathrm{s}^{-1}$. At each speed of the forward movement $V$ of the experimental installation, by changing the drive sprocket in the drive of the horizontal cleaning shafts, their rotation frequency was changed. The exact value of the angular rotational speeds $\omega$ of the horizontal cleaning shafts, recorded by the sensor mounted on the cardan shaft of the power take-off shaft of the aggregating tractor (Fig. 3), corresponds to the following values: $45.3,54.2$ and $75.4 \mathrm{rad} \cdot \mathrm{s}^{-1}$. The experimental field studies were carried out at a constant position of the cleaner of the sugar beet head in a vertical plane. This position was selected by us on the basis of the results of the technological experiments that showed the best indicators of the cleaning quality. In this case, the installation height of the ends of the cleaning blades was $1.5-2.5 \mathrm{~mm}$ from the level of the soil surface. Rubber blades, reinforced with cord, $0.20 \mathrm{~m}$ long, $0.05 \mathrm{~m}$ wide, were 
used as the cleaning blades. It should be noted that all the experimental field research was carried out in accordance with the developed program and methodology in five replicates for each value of the forward speed $V$ of the installation and for each fixed value of the angular velocity $\omega$ of the rotational movement of the drive cleaning shafts. The driving cleaning shafts during the experimental field studies were located in parallel.

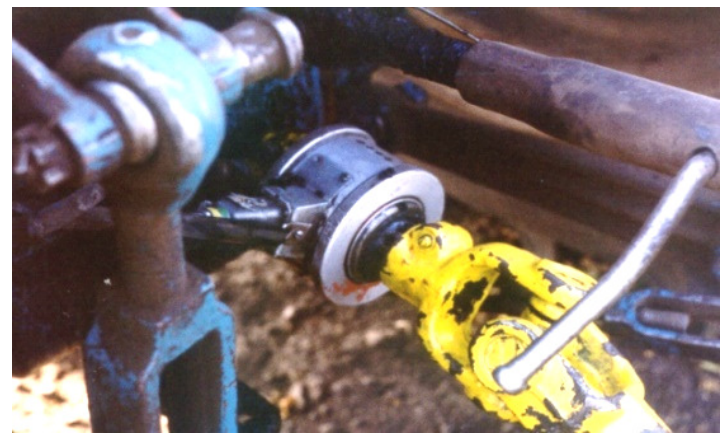

Fig. 3. Strain gauge sensor, mounted on the cardan shaft of the aggregating tractor

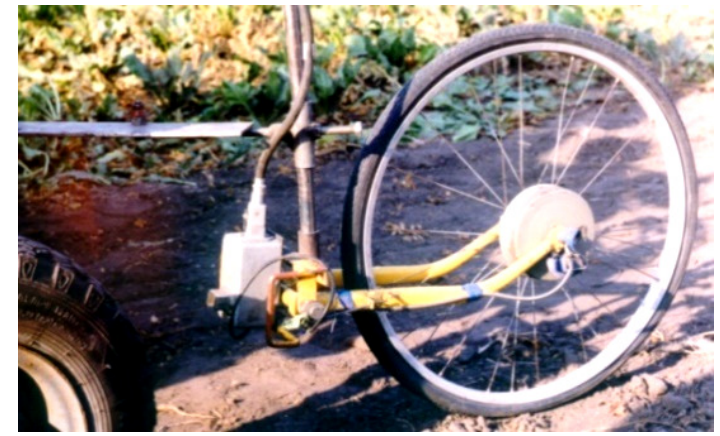

Fig. 4.Track measuring wheel

The experimental investigations were conducted in accordance with the program and methodology of a multi-factor experiment that we developed. Processing of the results was carried out by statistical methods, using the software package "IMESH STATISTICS" (Ukraine). As a result, the mean values, standard deviations and coefficients of the variation of the investigated parameters were obtained.

\section{Results and discussion}

Based on the results of the experimental studies of the energy parameters of the new cleaner of the sugar beet heads from the tops without extraction the heads from the ground, processed by statistical methods on the PC, graphical dependences of the power $N_{D}$ on the cleaner drive upon the forward speed $V$ of its movement at angular rotation speeds $\omega$ of its cleaning shafts are obtained (Fig. 5).

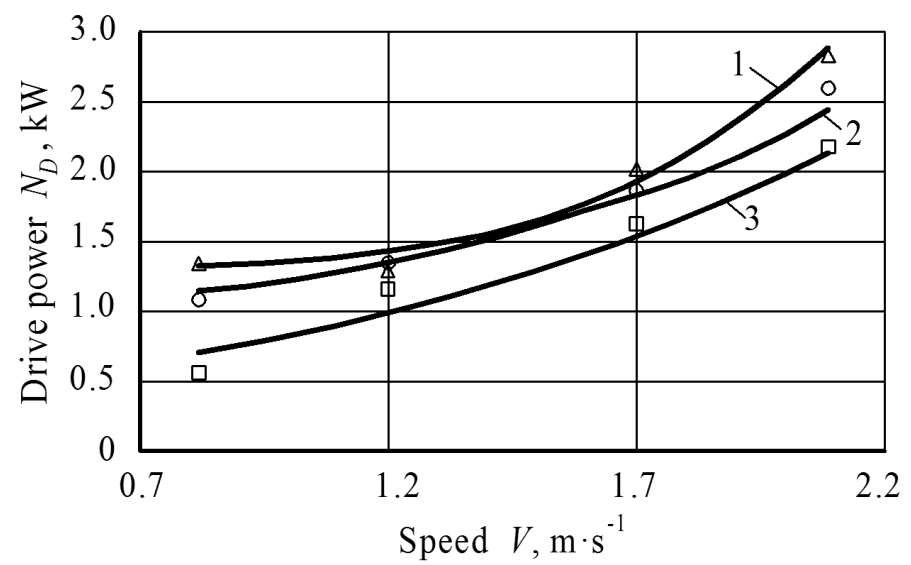

Fig. 5. Dependence of the power $N_{D}$ on the cleaner drive upon the forward speed $V$ of its movement at the angular speeds $\omega$ of rotation of the cleaning shafts:

$$
1-\omega=75.4 \mathrm{rad} \cdot \mathrm{s}^{-1} ; 2-\omega=54.2 \mathrm{rad} \cdot \mathrm{s}^{-1} ; 3-\omega=45.3 \mathrm{rad} \cdot \mathrm{s}^{-1}
$$

Fig. 6 shows dependences of the power $N_{T}$ on the drive of the cleaner upon the forward speed $V$ of its movement at the angular speeds $\omega$ of rotation of the cleaning shafts.

Having analysed the graphical dependencies presented in Fig. 5 and Fig. 6, we can conclude that the required power for the drive of the cleaning working bodies of the cleaner can reach $2.5 \mathrm{~kW}$. The maximum value of the traction power does not exceed $0.24 \mathrm{~kW}$. The total maximum power of this sugar beet cleaner from the remains of tops without extraction of the heads from the ground with horizontal drive shafts is $2.74 \mathrm{~kW}$. In terms of the cleaner, which can be executed in a six-row version, 
the total power can reach $16.44 \mathrm{~kW}$. If we compare similar energy indicators of the commercially available cleaner OGD-6 (B) of the sugar beet cleaner from the remains of tops without extracting the roots from the soil, then this is 1.3 times less.

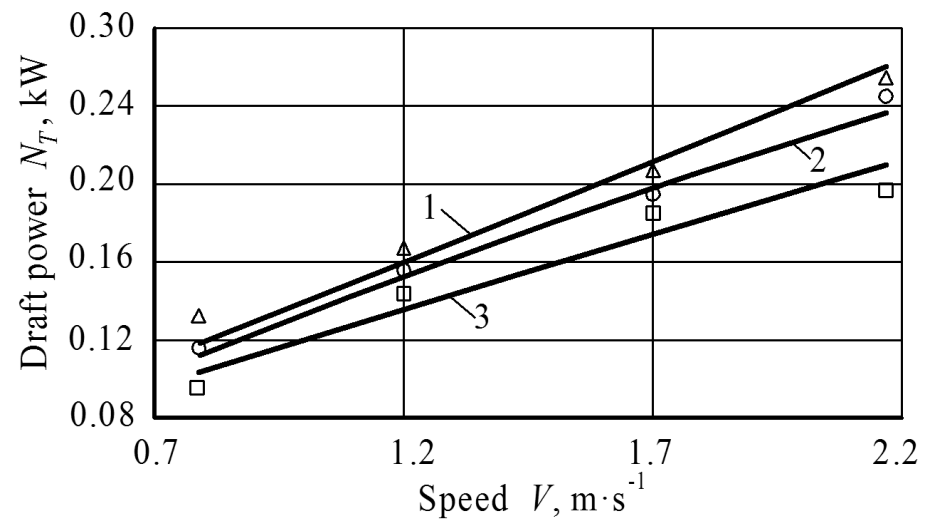

Fig. 6. Dependence of the traction power $N_{T}$ of the cleaner on the forward speed $V$ of its movement at angular speeds $\omega$ of rotation of the cleaning shafts:

$$
1-\omega=75.4 \mathrm{rad} \cdot \mathrm{s}^{-1} ; 2-\omega=54.2 \mathrm{rad} \cdot \mathrm{s}^{-1} ; 3-\omega=45.3 \mathrm{rad} \cdot \mathrm{s}^{-1}
$$

As it can be seen from the graphical dependencies, the rational modes of operation of the new cleaner of the sugar beet heads from the remaining tops, which ensure minimum energy consumption, is the forward speed $V$ of its movement, which is within the range of $1.5-1.7 \mathrm{~m} \cdot \mathrm{s}^{-1}$ at the angular rotation speed $\omega$ of the drive horizontal cleaning shafts, which should be within the range 46.0$55.0 \mathrm{rad} \cdot \mathrm{s}^{-1}$.

The obtained energy-power indices of the new design of the twin-shaft after-cleaner of the sugar beet heads from the tops slightly exceed similar indicators for the first-type after-cleaners by an average of $5-8 \%[10,11]$. This is due to the fact that the indicated design has actually two-drive cleaning shafts, each of which cleans only one of the sides of the sugar beet in the row of their plantation, which causes an increase in its energy and power indicators.

During the research of the energy-power characteristics of the new after-cleaner of root heads from the remains of the tops we also recorded qualitative indicators of its work. In addition, it was found that the performance indicators of this design are at the level or even exceed similar indicators of other type cleaners of the sugar beet heads from the remnants of tops [12].

\section{Conclusions}

1. The experimental measuring installation allows accurate determination of the energy indicators of this cleaner, provided that the technological process of cleaning the sugar beet heads from the remaining leaves is carried out in good quality.

2. As a result of statistical processing of the results of strain gauging on the PC, it was found that the maximum value of the required power on the drive of the working bodies of the cleaner can reach $2.5 \mathrm{~kW}$, and a similar value of traction power does not exceed $0.24 \mathrm{~kW}$. On the whole, the total maximum power of this sugar beet cleaner from the tops (remaining leaves) without extracting the sugar beet heads from the ground with horizontal drive shafts is $2.74 \mathrm{~kW}$, which is 1.3 times less than commercially available cleaners spend on it.

\section{Reference}

[1] Merkes R. 50 Jahre Prodaktionstechnik im Zuckerr. Benbau in Deutchland. Zuckerr., No 4, 2001, pp. 214-217.

[2] Vilde A. Development of technologies and machinery for production of sugar beet in Latvia. Proceedings of the conference "Safe and economical agricultural technologies" (25-26 July, 2002, Priekuli, Latvia), 2002. pp. 62-66.

[3] Погорілий Л.В. Бурякозбиральні машини: історія, конструкція, теорія, прогноз (Beet Harvesting Machines: history, design, theory, forecast). Київ: Фенікс, 2004, 232 р. (In Ukrainian). 
[4] Bulgakov V., Golovach I., Ivanovs S., Ihnatiev Y. Theoretical investigations in cleaning sugar beet heads from remnants of leaves by cleaning blade. Engineering for Rural Development, Vol. 16, pp. 288-295.

[5] Максаков В. Ботва, жом и мелисы при кормлении животных (The haulm, pulp and melissa when feeding animals). Киев: Урожай, 1993, 145 p. (In Russian).

[6] Bulgakov V., Ivanovs S., Adamchuk V., Boris A. Mathematical model for determination of losses of sugar bearing-mass when sugar beet tops are removed. Engineering for Rural Development, Vol. 14, 2015, p.p. 441-451.

[7] Хелемендик М.М. Напрями і методи розробки робочих органів сільськогосподарських машин (Directions and Methods for the Development of New Operating Tools of Agricultural Machines. A Monograph). Київ: Аграрна наука, 2001, 280 р. (In Ukrainian).

[8] ГОСТ 20915-2011. Методы определения условий испытаний. Испытания сельскохозяйственной техники (Testing of agricultural tractors and machines. Procedure for determination of test conditions), Москва, 2011, 47 p. (In Russian).

[9] Булгаков В. М. Зиков П. Ю., Орехівський В. Д.. Деклараційний патент України на винахід UA 29336 А. Спосіб доочищення головок коренеплодів і пристрій для його здійснення (Method for defoliation of root heads and device for its implementation. Ukrainian patent No UA 29336 A), 2000. (In Ukrainian).

[10] Bulgakov, V., Ivanovs, S., Santoro, F., Anifantis, A. S. Experimental investigation of the energypower characteristics of the cleaner of the root crop heads from the haulm. Engineering for Rural Development 18, pp. 129-135.

[11]Zhu Z., Teng X., Eisaka T. Simultaneous optimization of structural and control system for an agricultural machine. The International Workshop on Modern Science and Technology, 2008, pp. 632-637.

[12] Bulgakov V., Pascuzzi S., Arak M., Santoro F., Anifantis A.S., Olt J., Ihnatiev Ye. An experimental investigation of performance levels in a new root crown cleaner. Agronomy Research, Vol. 17, No 2, 2019, pp. 358-370. 